\title{
Vogt-Koyanagi-Harada disease: inquiry into the genesis of a disease name in the historical context of Switzerland and Japan
}

\author{
Carl P. Herbort · Manabu Mochizuki
}

Received: 12 March 2007/ Accepted: 20 March 2007/Published online: 28 April 2007

(C) Springer Science+Business Media B.V. 2007

\begin{abstract}
Purpose To delineate the historical steps associated with the genesis of the name and the definition of Vogt-Koyanagi-Harada (VKH) disease.

Methods A bibliographical review of the major publications that were relevant to the original development of the name of the clinical entity known today as Vogt-Koyanagi-Harada disease, in the historical context of the early 20th century.

Results Three distinct time periods can be considered to be important in terms of providing a historical perspective on VKH disease. Given that the cutaneous manifestations of VKH disease are so characteristic, these could not have been missed even before the actual clinical entity of VKH was recognized in the early 20th century. Indeed, several authors,
\end{abstract}

C. P. Herbort $(\bowtie)$

Inflammatory and Retinal Eye Diseases, Centre for Ophthalmic Specialized Care (COS), La Source Avenue des Bergières 2, Lausanne 1004, Switzerland

e-mail: carl.herb@bluewin.ch

\section{P. Herbort}

Foundation Memorial A. de Rothschild, Geneva,

Switzerland

C. P. Herbort

University of Lausanne, Lausanne, Switzerland

C. P. Herbort - M. Mochizuki

Department of Ophthalmology and Visual Science, Tokyo Medical and Dental University Graduate School, Tokyo, Japan including the Arabic doctor Mohammad-al-Ghâfiqî in the 12th century as well as Jacobi, Nettelship and Tay in the 19th century, described poliosis, neuralgias and hearing disorders. Many of these cases were probably due to sympathetic ophthalmia, but some were clearly VKH cases. The second phase is characterized by the surge of articles that appeared early in the 20th century that defined the disease more precisely. A number of these authors subsequently became associated with the disease name, the first being Alfred Vogt from Switzerland, followed by Japanese researchers. Yoshizo Koyanagi was in fact not the first Japanese author to describe the disease; this honor goes to the first Japanese Professor of Ophthalmology at the University of Tokyo, Dr. Jujiro Komoto, who published in a German language journal, Klinische Monatsblätter für Augenheilkunde in 1911. Yoshizo Koyanagi published his first report in the Nippon Ganka Gakkai Zasshi 3 years later, in 1914, but it was a much later article, one published in 1929 , that definitively associated his name with the disease. In this review article, Koyanagi reported 16 cases, of which six were his own cases, that beautifully illustrate the natural course of the disease. In this same time period, Einosuke Harada, in an article published in Nippon Ganka Gakkai Zasshi in 1926 that was based on several case studies, comprehensively described a syndrome that included (1) a prodromal phase of malaise and meningeal irritation; (2) bilateral uveitis of diverse intensity; (3) bilateral retinal detachments spontaneously resolving; 
(4) integumentary changes; (5) lymphocytosis of the spinal fluid; (6) dysacousia. It is now accepted that Vogt-Koyanagi disease and the syndrome described by Harada are one entity with a diverse clinical spectrum bearing the universally accepted name of Vogt-Koyanagi-Harada disease. The third phase and most recent phase is characterized by the rapid progress made in terms of knowledge of the physiopathology of the disease, primarily due to the development of immunological methods. The evidence accumulated to date clearly points towards an autoimmune Th1 disease directed against proteins associated with choroidal melanin. Other analytical techniques, such as indocyanine green angiography, have enabled researchers to monitor more closely the primary lesional process at the level of the choroid, and standardized diagnostic criteria have been generated in the recent past.

Conclusion Those who earn scientific merit in clinical medicine are the ones who are able to visualize an overview based on the synthesis of 'new' medical facts that have been made available, usually reported singly by several, unassociated authors concomitantly. This is certainly the case for Yoshizo Koyanagi and Einosuke Harada. Conversely, Alfred Vogt was primarily lucky in that he encountered and subsequently precisely described the first case in the literature.

Keywords History · Japan - Switzerland · VogtKoyanagi-Harada disease

\section{Introduction}

In this historical essay, which takes both personalities and historical background into account, the authors relate the Swiss and Japanese points of view on how the name Vogt-Koyanagi-Harada disease came into being. This eponym designates a fascinating disease that is still unveiling its secrets as immunological research and progress in investigational methods enable researchers to gain a better understanding of the genesis of the disease and its mechanisms. The sole player in the first act in terms of defining VogtKoyanagi-Harada (VKH) disease was the Swiss ophthalmologist Alfred Vogt, who, in 1906, when he was still a resident in the Department of Ophthalmology of Basel University Hospital, published a case report in which he described what is now known as VKH disease for the first time [1]. The second act occurred on the opposite side of the world, in Japan, where Western medicine was barely 40 years old: several Japanese authors described different aspects of the disease, and the names of Yoshizo Koyanagi and Einosuke Harada remain figuratively attached to the disease that today is described comprehensively as a bilateral granulomatous uveitis that initially can involve only the posterior segment or can present as a panuveitis and which is most probably caused by a Th1 autoimmune reaction against proteins related with stromal choroidal melanocytes [2-3]. The fact that the name of a Swiss ophthalmologist, Alfred Vogt, is linked to the names of two Japanese ophthalmologists, Yoshizo Koyanagi and Einosuke Harada, should be put into the proper historical perspective and medical historical context of the beginning of the 20th century, both in Europe and Japan.

\section{The 'pre-VKH' reports}

The depigmentation of eyelashes and eyebrows is such a remarkable and peculiar finding that it has been readily recorded and described in the past. In the 12th century, the Arabic doctor Mohammad-alGhâfiqî mentions the occurrence of poliosis in his book on eye diseases [4]. In the 19th century, poliosis is described by several authors and associated with a nervous choc, neuralgias or a physical trauma [5-7]. It can be hypothesized that some of these descriptions possibly represented VKH disease as (1) neuralgias might have corresponded to the headaches usually associated with VKH and (2) trauma, even to body parts distant from the eye, has been shown in the past and also recently to possibly be at the origin of $\mathrm{VKH}$ cases [8]. However, poliosis of the eyelashes and eyebrows together with hearing problems were the more frequent symptoms associated with sympathetic ophthalmia [9-10].

\section{The medico-historical context of Japanese ophthalmology in the early 20th century}

In order to realize how quickly Japanese medicine in general and Japanese ophthalmology in particular closed the immense gap that had been generated by 
the 250 years of closed border policy of the Tokugawa period (1600-1868), it is necessary to make a quick digression into general history.

In January 1867 a new emperor acceded to the Japanese throne. He took the name of Meiji (enlightened rule), and his reign signaled the beginning of an era that would see radical changes in all aspects of Japanese life, including those that comprehensively determined Japanese medical destiny. This emperor was aged only 15 at the time he became emperor, and his destiny was to be taken into custody by the political forces fiercely opposed to the 250-year-long Tokugawa military (samurai) government, which had been judged to be too inapt to deal with the foreign pressures on Japan [11]. On January 3, 1868, these forces, primarily from the southern provinces which had been kept out of state affairs during the past 250 years, occupied the imperial palace and declared imperial rule in the name of the emperor. The last Tokugawa shogun, in place only 1 year and despite his having contributed to the positive evolution and modernization of the nation, preferred to relinquish power. By so doing, Tokugawa Yoshinobu, a progressively oriented and very distinguished personality - and one forgotten by history - probably made a very significant contribution to the modernization of Japan by avoiding a potentially devastating civil war that would have postponed Japanese modernization by years [12]. It has to be pointed out, however, that contrary to what is currently believed, the political forces that are now credited for the modernization of Japan performed their 'coup d'état' for precisely the opposite motives: they wanted to overthrow Tokugawa Yoshinobu because they judged him too progressive as shown by his signing treaties with foreigners; in contrast, the new political forces wished to keep the country closed to outside influences. However, events would push them to do exactly what the last shogun had begun, modernization through intense contacts and learning from foreigners. A very determined and carefully planned exploration of the best sources to acquire western know-how in all domains was put on track and resulted in the construction of a modern and powerful nation that defeated Imperial Russia in the Russo-Japanese war at the beginning of the 20th century. This fast-pace modernization also contributed to the development of (Western) medicine.
On March 8, 1868 the new government issued a decree saying 'Western medicine has been prohibited in the Imperial Court, but its advanced part may hereafter be adopted' [13]. Jun Iwasa, who had been taught medicine in Japan by Antonius Franciscus Bauduin, a Dutch teacher of medicine whose family was originally from France, was appointed by the new government as the officer in charge of medical education. It was now the task of the Bureau of Medical Affairs, created and headed by Jun Iwasa since January 23, 1869, to choose the foreign medical educational system that would be imported into Japan. At that time, three influential Western teachers of medicine, Antonius Franziskus Bauduin and Guido Herman Fridolin Verbeck from the Netherlands and William Willis, a British physician, advised the Japanese to adopt the German medical educational system. The large Japanese interdisciplinary delegation headed by Tomomi Iwakura that embarked on a round-the-world journey on October 8, 1871 to study all the vital aspects and systems, including educational and medical systems of Western nations, also stopped in Germany and established the basis of what would become a very close relationship in the medical field until the end of World War II. Many Japanese doctors received their medical education and specialization in German medical schools, and many German medical teachers came to Japan. The German language was adopted for all medical matters, and it became quite natural for Japanese doctors to publish their research in German medical journals. Therefore, it is no surprise that the original article on VKH disease by the German-speaking Swiss ophthalmologist Alfred Vogt in 1906 and that of Yoshizo Koyanagi in 1929, in which he extensively reviews $16 \mathrm{VKH}$ cases, were published in the same German journal Klinische Monatsblätter für Augenheilkunde.

In the ophthalmological field, Kinnojo Ume was the first Japanese lecturer, replacing a German teacher in 1883 after he had returned from Germany; following the death of Kinnojo Ume, his position at Tokyo University was filled by Jujiro Komoto, also trained in Germany, who subsequently became the first appointed Professor of Ophthalmology in 1889. In 1893, Jujiro Komoto published the first Japanese textbook for ophthalmology. The Japanese Society of Ophthalmology was founded in 1896, with Professor Komoto as its first president, and the first congress 
was held in February 1897, which is also the first year that its journal was published (Nippon Ganka Gakkai Zasshi). One of the historical events that had a direct influence on Japanese ophthalmology was the RussoJapanese war: Japanese ophthalmologists became experts in sympathetic ophthalmia, a clinical picture to which the first cases of VKH were compared, with the difference that no traumatism occurred in the latter.

\section{The first act, Switzerland}

The article princeps (1906) (Fig. 1)

In 1906, at the age of 27, Alfred Vogt, who was still a resident in the department of ophthalmology at Basel University Hospital in northern Switzerland, published a case report which he entitled 'Premature whitening of eyelashes and comments about the socalled sudden onset of this change' [1]. Vogt published his case report in Klinische Monatsblätter für Augenheilkunde. The patient was an 18-year-old peasant. Although the ethnic origin of the patient is not given, based on the published photograph he seems to have a dark complexion, and his face does not appear to have a northern Caucasian countenance but more of a Southern, Middle Eastern or North African one (Fig. 2). The article was 14 pages long, and the part devoted to uveitis takes up exactly five lines and can be translated from German as follows: 'The eyeballs with ciliary injection showed the usual image of subacute iridocyclitis. Because of the exudates and the keratic precipitates, the previous

XIX.

Aus der Universitäts-Augenklinik Basel. (Prof. Dr. C. Mellinger.)

Frühzeitiges Ergrauen der Zilien und Bemerkungen über den sogenannten plötzlichen Eintritt dieser Veränderung.

Von Dr. Alfred Vogt, I. Assistenzarzt.

Mit 1 Abbildung.

Am 1. April vorigen Jahres wurde ein 18jähriger Bauernbursche wegen schwerer beiderseitiger Iridozyklitis, die angeblich seit 5 Wochen bestand, in unsere Behandlung aufgenommen. Die Anamnese zeigte nichts Besonderes. Patient war blass und von etwas gedunsenem skrofulösem Habitus. Die Augenlider waren ohne Besonderheiten. Die ziliar injizierten Bulbi zeigten das gewöhnliche Bild subakuter Iridezyklitis. Durch Exsudate und Hornhautpräzipitate war das früher angeblich gute Sehvermögen rechts auf $4 / 200$, links auf $3 / 200$ herabgesetzt.

Fig. 1 First page of the article written by Alfred Vogt in 1906

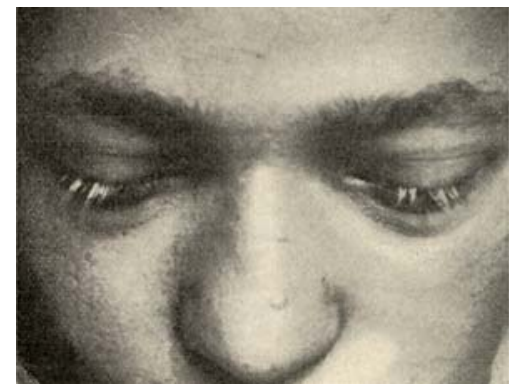

Fig. 2 Face of the first patient with Vogt-Koyanagi-Harada (VKH) disease described by Alfred Vogt in his 1906 article showing bilateral eyelash discoloration (poliosis)

visual acuity reported as normal, was decreased to 4/ 200 on the right and 3/200 on the left side. The inflammation was resistant to all therapeutical attempts, in as much as apparent resolution of inflammation was always followed by new exacerbations'. The remainder of the report (14 pages minus these five lines) are nearly exclusively devoted to the possible genesis of the whitening of eyelashes and whether they appear all of a sudden or take some time to develop and become apparent. His literature search also does not concentrate on uveitis but only on reported cases of eyelash whitening (poliosis). The literal translation of the term poliosis from Greek is 'becoming grey'. Vogt then reports cases of poliosis reported in the literature, most of which were associated with sympathetic ophthalmia. The absence of any comment and even the absence of interest of Vogt for the uveitis or other complications, such as dysacousis, indicates that he put his finger on this first described case of VKH disease quite by chance and that he was not really aware of all the intraocular inflammatory implications of the case which, in fact, he merely described with precision, mainly focusing on the eyelash problem.

Alfred Vogt and Swiss ophthalmology in the first third of the 20th century

Alfred Vogt (1879-1943) (Fig. 3) [14-15]

Alfred Vogt was born in 1879, 1 year earlier than Yoshizo Koyanagi (1880) and 13 years earlier than Einosuke Harada (1892), in the canton of Argau in the German-speaking region of northern Switzerland. $\mathrm{He}$ attended medical school at the universities of 


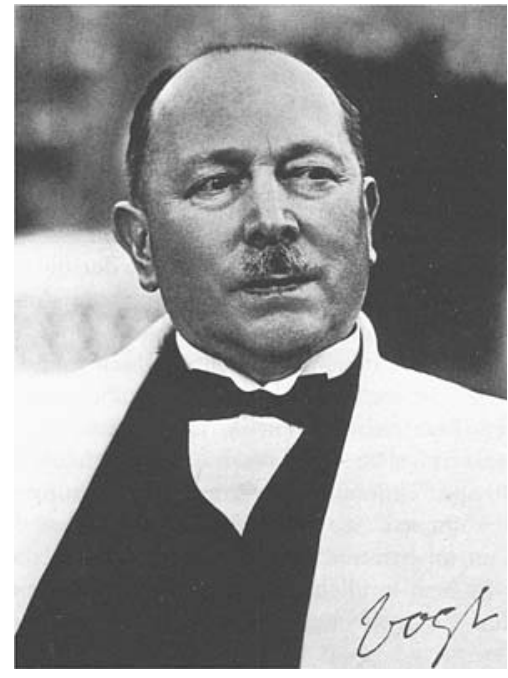

Fig. 3 Alfred Vogt (1879-1943)

Zurich and then Basel, where he graduated in 1904 at the age of 25 . He received his ophthalmological training from 1904 to 1906 in Basel. It was during this period, when he was still a 'medical resident' that he reported the first case of an entity that would eventually be designated Vogt-Koyanagi-Harada disease [1]. From 1906 to 1917 he returned to his canton of Argau, where he became the director of the Department of Ophthalmology of the Kantonsspital (County Hospital). During this period he carried out notable work on the yellow coloration of the macula, which since 1945 is known to be due to intracellular xantophyll pigment. In 1917 he was nominated to become the chairman of the Department of Ophthalmology of Basel University Hospital, as yet without completing his thesis (Fig. 4).

The government of Canton Basel nominated Vogt against the will of the Medical Faculty. His relations with the Basel Medical Faculty were not excellent, and the value of his scientific work was not appreciated and judged too 'specialistic' and morphologystic', whatever this may mean. In 1921 he published the first edition of what would become a monument in three volumes of didactic ophthalmology entitled Atlas of slit-lamp microscopy of the living eye (Fig. 5).

Because of the cold response of the Medical Faculty and failing recognition for his work in Basel, he did not hesitate one moment to accept the chairmanship of the Department of Ophthalmology

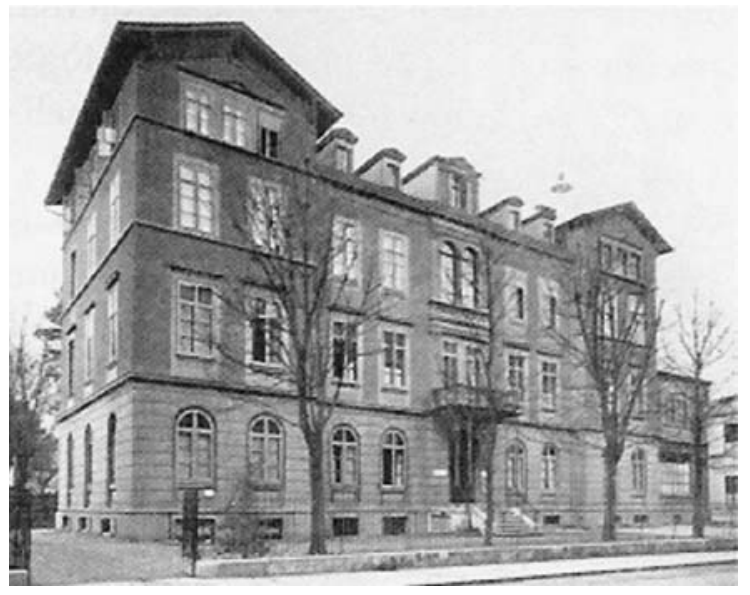

Fig. 4 Basel University Eye Clinic at the beginning of the 20th century

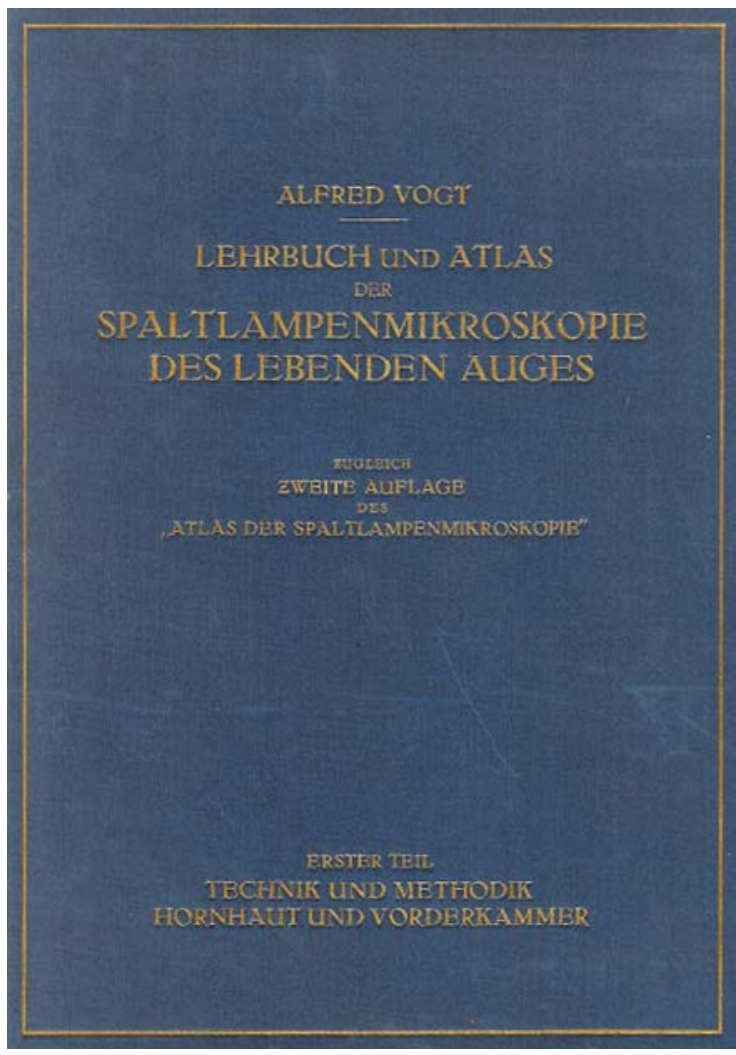

Fig. 5 First volume (second edition) of Vogt's Atlas of slitlamp examination of the eye published in 1930

of Zurich University Hospital, which was offered to him in 1923, declining even to hold a farewell dinner in Basel. His welcome lecture in Zurich was on the 
physiological and pathological effects of light rays on the eye, indicating his interest in the different factors at the origin of the development of cataracts. During his time in Zurich, publications followed one after another on slit-lamp findings, describing the cornea guttata, cataracta centralis pulverata, persistence of anterior hyaloid membrane, chalkosis and siderosis of the lens, the degeneration of the papillo-macular nerve-fiber bundle and many other aspects. For his work in these areas, he received in 1937 the Dondersmedall from the Dutch Ophthalmological Society. He was furthermore awarded the Gullstrand-medall and in 1941 the Gonin-medall. During the second world war he generously supported and contributed to the survival of Klinische Monatsblätter für Augenheilkunde, the journal that has contributed so much to the exchanges between Japanese ophthalmologists and their colleagues in German-speaking Europe. He remained as chairman of the Department of Ophthalmology in Zurich until August 1943; however, due to failing health, the practical day-to-day tasks had been taken over by Professor Wagner in the fall of 1942. Alfred Vogt died on December 10, 1943.

\section{Swiss ophthalmology in the first third of the 20th century [16]}

At the beginning of the 20th century, there were five medical schools and university hospitals in Switzerland - in the cities of Basel, Bern, Geneva, Lausanne and Zurich, respectively.

The departments of ophthalmology of these medical institutions provided the sound foundations on which modern Swiss ophthalmology has based its quality and success from the 1930s onwards. The strong personality of Alfred Vogt left its mark on the departments of ophthalmology in Zurich and Basel during the first third of the 20th century. In Bern, the first third of the 20th century was marked by the construction of a large and modern new eye hospital that became functional at the end of the first decade, and it is due to the presence of such a large and wellequipped eye hospital that the significant scientific contributions of Hans Goldman emerged. Hans Golmann was appointed chairman in 1935. His name is directly associated with the development of indispensable investigative instruments that are still used every day in practice, such as the Goldmann applanation tonometer and the Goldmann visual field.
In Geneva, the first eye hospital built at the end of the 19th century was not associated with the university hospital. It was a hospital offered to the city by the baron Adolphe de Rothschild, who had been treated in Geneva for a corneal foreign body during one of his trips. This hospital continued in operation even after the university eye hospital was built in 1921 and it now functions as the Memorial A. de Rothschild, the main private ophthalmological facility in Geneva. In 1933, Adolphe Franceschetti was appointed chairman in Geneva and marked the apogee of the Geneva Department of Ophthalmology with pioneering work in oculogenetics. Ophthalmology in Lausanne was marked by the foundation in 1843 of the 'Fondation Asile des Aveugles' (Foundation Home for the Blind). When the medical school was founded in 1890, the Department of Ophthalmology of the University of Lausanne was run by the 'Foundation', and its medical director was also the chairman of the Department of Ophthalmology. In 1918, Jules Gonin became the new medical director of the hospital of the Foundation, but the university appointed a French professor and opened a department of ophthalmology within the university hospital. The reputation of the 'Foundation' hospital was such, however, that the university had to close down its department 2 years later, and Jules Gonin was named Professor of Ophthalmology in 1920 in addition being director of the 'Foundation' hospital. During the 1920s Jules Gonin discovered the pathogenesis of 'idiopathic' (rhegmatogenous) retinal detachment and its surgical treatment. Jules Gonin had the greatest difficulties getting his work accepted and was even considered to be a heretic when he proposed displacing the wall of the eye towards the retina to repair retinal detachment. It is now accepted universally that he is the father of retinal detachment surgery and the Lausanne University Eye Hospital (Hôpital Jules Gonin), a scientific society (the Club Jules Gonin) and a prestigious Medall-award (the Jules Gonin medall) are named after him.

On the national level, the Swiss Society of Ophthalmology was founded in 1908, 11 years after the foundation of the Japanese Society of Ophthalmology, and it is celebrating its 100th anniversary this year in 2007. That such a national society was established relatively late can be explained by the fact that, academically, the Swiss ophthalmologists at the end of the 19th century were educated abroad and 
turned towards Germany for German-speaking Swiss ophthalmologists and towards France for the Frenchspeaking Swiss ophthalmologists. Thus, the Swiss ophthalmologist Friederich Horner was a founding member together with von Graefe and Donders, of the Heidelberg Ophthalmic Society, established in 1863. As was the case for the Japanese ophthalmologists, publications were sent abroad - either to Germany to the Graefe's Archiv für Augenheikunde, which was founded in 1854, or to the Klinische Monatsblätter für Augenheilkunde, which was founded in 1863, or to France, to the Annales d'oculistique, founded in 1838. The stimulus for the establishment of a Swiss Society of Ophthalmology originated in the organization of the Tenth International Congress of Ophthalmology, in Lucerne. Switzerland was granted the honor of hosting this congress both in recognition of well-known Swiss ophthalmologists and due to the influence of Swiss ophthalmologists occupying positions abroad, such as Professor Edmond Landolt in Paris. The two Japanese ophthalmologists that participated in that congress were Tatsu Naito and Genzo Hotta, the latter staying in Breslau with Professor Uhthoff from whom he received his ophthalmological education between 1903 and 1905. All of the renowned Swiss ophthalmologists, including Auguste Barde, Head of the Rothschild Hospital in Geneva, and Marc Dufour, the "Foundation" hospital in Lausanne, as well as Swiss ophthalmologists working abroad, such as Edmond Landolt from Paris, were involved in organizing this event in 1904, which was attended by 440 ophthalmologists worldwide. The germs of the future society sprang from this congress, and it was finally founded in 1908. The Lucerne congress was very successful scientifically, but the congress attendants also enjoyed excursions to the Rigi heights and its idyllic atmosphere and panorama as well as to the Pilatus mountain, two very popular touristic spots specially appreciated still today by Japanese tourists.

In summary, the link between Switzerland and Japan in terms of VKH disease is a very tiny one and one completely determined by chance, as the first case logically should not have been described in Switzerland where VKH is a rare occurrence. The fact that the patient described by Vogt was probably of Mediterranean origin was the chance factor that determined that the name of this entity contains a non-Japanese name.

\section{The second act, Japan}

Early reports of Japanese cases of VKH (1911)

With the high incidence of VKH disease occurring in Japan, it is easy to understand that most of the pioneering work done on $\mathrm{VKH}$ disease comes from Japan.

In his review article of 1929, which established the semiology of the disease that is known today as Vogt-Koyanagi-Harada disease, Yoshizo Koyanagi cited his very first article on the disease and included the two patients reported in it. This first article appeared in the Nippon Ganka Gakkai Zashii in 1914 and described two patients presenting with a uveitis resembling sympathetic ophthalmia but without a history of trauma; in addition, one patient also showed integumetary changes together with dysacousis [17]. Koyanagi also cited the case reported by Vogt in 1906 and was astonished - as we were when we read the original article - that Vogt only showed interest for the poliosis, giving only scarce attention to the uveitis. In his review article, Koyanagi cites another case that was published by J. Komoto in 1911 in the Klinische Monatsblätter für Augenheilkunde, prior to his own first case report $[17,18]$. Thus, the first Japanese description of Vogt-Koyanagi-Harada disease has to be accredited to Jujiro Komoto (Fig. 6) In his article, Professor Komoto describes the case a 33-year-old wife of a fish merchant that came to his private clinic and presented the typical prodromal systemic symptoms followed by a bilateral decrease of vision and the occurrence of poliosis [18]. The article describes very precisely the fundus which corresponds to what is known today as sunset glow fundus. Professor Komoto noticed that the fundus resembled that of an albinotic fundus except that there were disseminated clumps of pigment. He very appropriately indicated that the retina itself seemed to be relatively untouched, having noticed that the disease involved primarily the choroid.

XII.

Aus der Privat-Augenklinik von Prof. Dr. J. Komoto, Tokio.

\section{Ueber Vitiligo und Auge. \\ Von Prof. Dr. J. Komoto.}

Fig. 6 First page of the first Japanese report of a VKH case presented by Professor Komoto 
The review article of Yoshizo Koyanagi (1929)

(Fig. 7)

The review article which Yoshizo Koyanagi published in 1929 in the Klinische Monatsblätter für Augenheilkunde was absolutely remarkable in several aspects [19] (Fig. 8). In this review article he reported his first two cases published in 1914 and added four new cases of his own; he then went on to cite ten cases taken from the literature, including one case published by Hata and Harada in 1919 [20], 7 years before Harada wrote his main article in 1926, and the first case reported by Vogt. In his introduction, Koyanagi expressed his astonishment that, after the first case described by Vogt, there were absolutely no other reports coming from outside Japan, implicitly indicating the preponderant occurrence of the disease in Japan. Koyanagi's description of the disease is precise and complete, including the prodromal phase, the acute ocular phase with the posterior involvement - which he calls neuroretinitis - the anterior participation of the disease with large non-pigmented KPs and the hypotony, which he attributes to ciliary body inflammation (Fig. 9a). He further described the fundus depigmentation in the convalescent phase of the disease (Fig. 9b). He is also the first author to unequivocally associate auditory and integumentary manifestations to the disease entity. As no treatment was available at that time, the article is remarkable for its precise description of the natural course of VKH disease. Auditory involvement was noted in 8/ 16 cases and occurred concomitantly to the eye involvement. Integumentary changes (alopecia and poliosis) occurred in all 16 cases (100\%) and developed after a mean of $7.43 \pm 3.36$ weeks after the acute episode, whereas vitiligo was only noted in $9 / 16$ cases $(56 \%)$. The only element that does not fit with the disease profile in this review are the results of cerebrospinal fluid (CSF) investigations, which are

XXII.

Aus der Augenklinik der Tohoku-Universität in Sendai, Japan. Dysakusis, Alopecia und Poliosis bei schwerer Uveitis nicht traumatischen Ursprungs.

Von Prof. Dr. Y. Koyanagi.

Mit 5 Textabbildungen, darunter 2 farbige auf Tafel IV.

Fig. 7 Title page of the review article by Yoshizo Koyanagi published in the year 1929

\section{KLINISCHE MONATSBLÄTTER FUR AUGENHEILKUNDE \\ UND FÛ̃R AUGENÄRZTLICHE FORTBILDUNG}

\section{BEGRÜNDET VON W. VON ZEHENDER}

UNTER MITWIRKUNG VON

Prof. ASK (Lund), Prof. BEHR (Hamburg), Prof. BIELSCHOWSKY (Breslau), Prof. BIETTI (Bologna), Prof.BIRCH-HIRSCHFELD(Königsberg), Prof. BLESSIG (Dorpat),Prof.BRÓCKNER(Basel),Prof.DEMARIA(BuenosAires),Prof.ELSCHNIG (Prag), Prof. FLEISCHER(Erlangen), Prof.E.FUCHS(Wien), Prof.daGAMA-PINTO (Lissabon), Dr. S. R. GIFFORD (Omaha, U.S.A.), Prof. GROENHOLM (Helsing(Lissabon), Dr. S. R. GIFFORD (Omaha, U.S.A.), Prof. GROENHOLM (Helsing-
fors), Prof.GROENOUW (Breslau), Prof. von GROSZ (Budapest), Prof.GRUETER (Marburg), Prof. GRUNERT (Bremen), Prof. GULLSTRAND (Upsala), Prof. HAGEN(Oslo), Prof. HEINE (Kiel), Prof. HERTEL (Leipzig), Prof. E. von HIPPEL (Gơttingen), Prof. van der HOEVE(Leiden), Prof. ISHIHARA (Tokio), Prof. JESS (Giessen), Prof. KOMOTO (Tokio), Prof. KROCCKMANN (Berlin), Prof. LINDNER (Wien), Prof.LÖHLEIN(Jena), Prof.LUNDSGAARD(Kopenhagen), Prof.MARQUEZ (Madrid), Prof. MELLER (Wien), Dr. MENACHO (Barcelona), Prof. MIYASHITA (Tokio), Doz.Dr.LeopoldMÓLLER(Wien), Prof.ODINZOW(Moskau), Prof.OELLER (Erlangen), Prof.PASCHEFF (Sofia), Prof.PETERS(Rostock), Prof.PROEBSTING (Kőln), Prof. ROCHAT (Groningen), Prof. SALZMANN (Graz), Prof. SCHIECK (Würzburg), Prof. SCHNAUDIGEL (Frankfurt a. M.), Prof. SEEFELDER (Innsbruck), Prof. SIEGRIST (Bern), Prof. R. SILVA (Mexiko), Prof.STOCK (Túbingen), Prof. VOGT (Zürich), Prof. WILBRAND (Hamburg), Prof. ZEEMAN (Amsterdam). HERAUSGEOEBEN VON

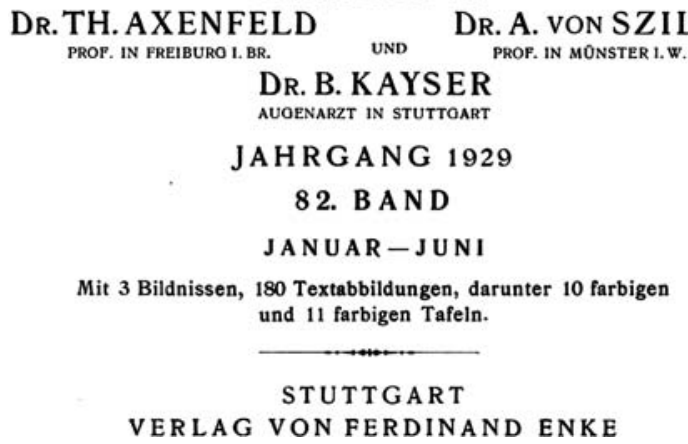

Fig. 8 Title page of volume 82 of the Klinische Monatsblätter für Augenheilkunde in which the review article of Yoshizo Koyanagi was published in 1929

reported as non-inflammatory. However, few details are given on how many lumbar punctures were performed and how the CSF was analyzed. As far as the pathogenic mechanism is concerned, Koyanagi and others were not far from the correct hypothesis of an immune reaction against pigment, which at this epoch was called an 'anaphylactoid' reaction. In terms of the etiology, Koyanagi did not yield to the tendency at that time of attributing many conditions to syphilis. In the discussion section of his article his logical conclusion and new interpretation was, in contrast to previous and contemporary reports [10], that the auditory and skin lesions were not a consequence of the eye disease but resulted from the same pathogenic mechanism at the origin of eye disease, as auditory involvement, in particular, was 


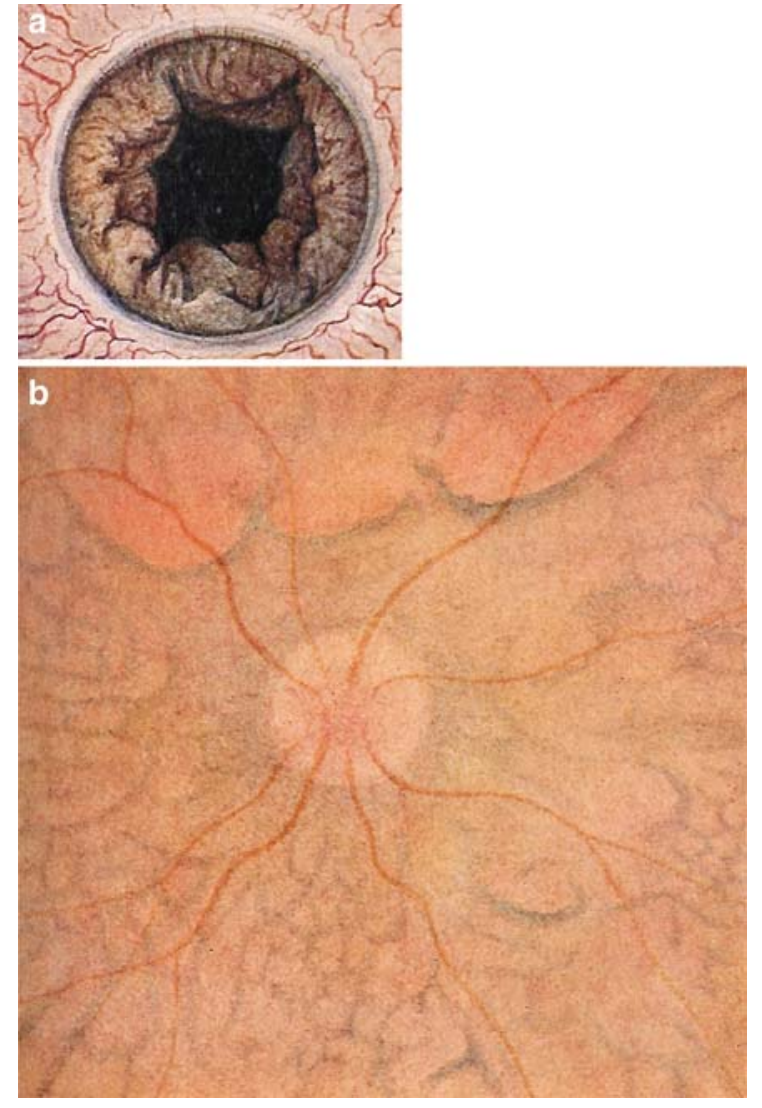

Fig. 9 (a) Anterior involvement in VKH, (b) posterior involvement in $\mathrm{VKH}$ showing sunset glow fundus. Both drawings are taken from the 1929 article by Koyanagi

seen to occur quasi simultaneously to the eye involvement.

Yoshizo Koyanagi (1880-1954) (Fig. 10)

Similar to many of the Japanese historical facts reported in this article, the biographical elements on Professor Yoshizo Koyanagi were taken from Professor Saiichi Mishima's book on The History of Ophthalmology in Japan [21]. Yoshizo Koyanagi was born in 1880. He graduated from Kyoto Imperial University in 1908 and studied ophthalmology under Ikujiro Asayama, the first Professor of Ophthalmology at Kyoto Imperial University and the first author to describe a case of central serous chorioretinopathy. His teacher was also the first Japanese ophthalmologist to attend an International Congress of Ophthalmology (the ninth congress in Utrecht in 1899).

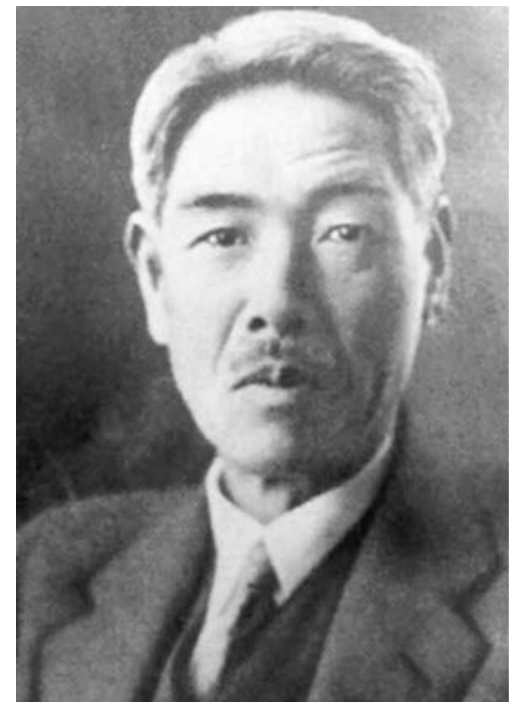

Fig. 10 Yoshizo Koyanagi (1880-1954)

In 1914 Yoshizo Koyanagi published a first article on the disease that would eventually bear his name in which he reported two patients who had all the characteristics of VKH disease [17]. In 1915, he became the first Professor of Ophthalmology in the newly founded Tohoku Imperial University in Sendai. In 1929, Koyanagi wrote the review article in which he reported 16 cases of what would eventually be known as VKH disease, ten of which were the result of a literature search. It is this comprehensive review article, which in fact was the first to report the natural course of non-treated VKH disease, which linked the name of Koyanagi to this particular ocular inflammatory disease. Koyanagi became a worldfamous ophthalmic pathologist and gave a special report on retinal pathology at the Fifteenth International Congress of Ophthalmology in Cairo in 1937. In 1942, Yoshizo Koyanagi retired from the professorship of Tohoku Imperial University, and he died in 1954.

Harada's disease (1926) (Fig. 11) [22, 23]

In 1923, Einosuke Harada reported a case of peculiar uveitis, heretofore unknown; he subsequently identified three more cases in 1925 [22]. In 1926, he reported five cases analyzed in detail, including the four earlier cases, under the name of 'acute diffuse choroiditis' in the journal Nihon Ganka Gakkai 


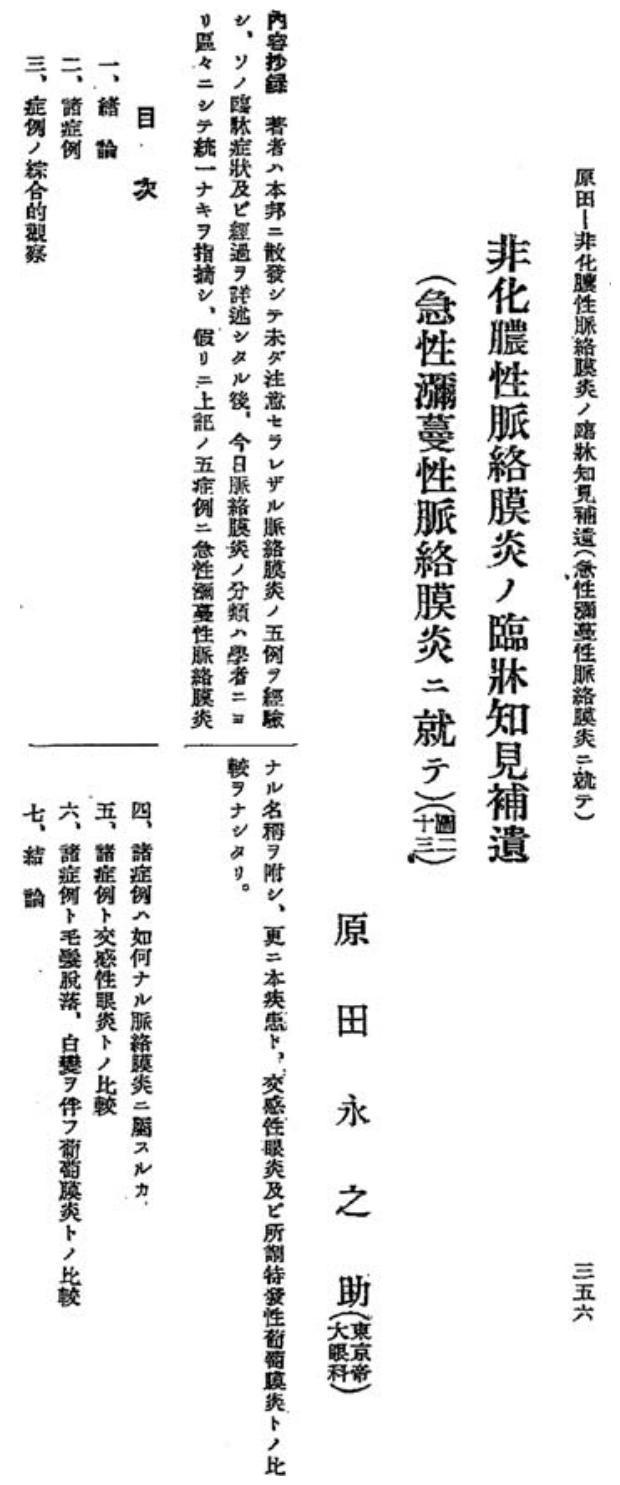

Fig. 11 First page of Harada's main article published in 1926

Zasshi [23]. The five patients reported by Harada were Japanese and aged 47 (man), 24 (woman), 20 (man), 27 (woman) and 25 (man). Three patients were from Tokyo, while the other two were from districts away from Tokyo. Harada observed a full clinical course in these patients from the disease onset until a few years later, and he recognized that the patients exhibited unique clinical appearances which were quite different from one disease stage to the other. He summarized the clinical pictures of the five cases as follows.
The patients developed a sudden onset of visual disturbance in both eyes, either simultaneously or with a few days delay from one eye to the other. The visual disturbance reached its peak several days after onset. During or prior to these ocular episodes, patients complained of headache and poor appetite, conditions which lasted for about 1 month. Some patients complained of nausea and vomiting on several occasions during this period. In the acute early stage of the disease, the cornea, anterior chamber and the iris appeared as normal, but the pupil was dilated and the light reflex was not prompt. Ophthalmic examination at the acute stage revealed neuroretinitis and later vitreous opacities and retinochoroiditis. The ocular inflammation progressed rapidly or slowly to the peripheral fundus and developed into intense chorio-retinitis. All five patients developed intense edema of the optic disc and the retina near the optic disc followed by retinal detachment near the optic disc. The patients became hypermetropic up to $6 \mathrm{D}$ to $7 \mathrm{D}$ and had visual field defects together with intense visual loss. With the progress of inflammation, the exudative retinal detachments expanded down to the inferior fundus. Two to three months after onset, the retinal detachment improved and disappeared with gradual recovery of visual function. However, diffuse choroiditis persisted and relapsed. It took several months until complete remission of the ocular inflammation. In all five patients, the ocular fundus after the recovery from ocular inflammation resembled the fundus of Caucasians in that choroidal blood vessels were clearly visible. There were some pigment migrations, pigment clumpings, atrophic lesions in the fundus, atrophy of the retina and the choroid, exposure of the sclera by fundus examination and some fibrinous tissue formation. The visual functions of these patients depended on the changes in the ocular fundus in each case. Harada reported alopecia and poliosis in one patient of his series. Lumbar puncture was performed in three patients between day 17 and day 19 after disease onset, and pleocytosis (described as 'precipitates in his manuscript) was found in one patient. In summary, the common findings in Harada's cases were acute bilateral onset of posterior uveitis with exudates, resulting in focal retinal detachments. After the inflammation subsided, defuse depigmentation became evident, and the fundus showed a sunset glow appearance. Poliosis and 
vertigo were accompanying symptoms, and there was polycytosis in the spinal fluid. The disease often relapsed and was seen to take a chronic course. Similar cases were reported abroad later, and these were called Harada's disease [24]. Thus, the concept of Harada's disease became widely accepted in the world.

Einosuke Harada (1892-1946) (Fig. 12) [21]

Einosuke Harada was born in 1892, 12 years later than Yoshizo Koyanagi. He graduated form Tokyo University in 1917 and became an army surgeon.

From 1923 to 1925 he studied ophthalmology as an assistant to Professor Ishihara. He then carried out research at the Department of Pharmacology of Tokyo University where he completed his dissertation on 'Experimental studies on changes of the aqueous humor by various drugs' and received the degree of doctor of medical sciences (DMSc) in 1929. He practiced in Nagasaki in the hospital of his father-in-law thereafter but was drafted in 1943 to the battlefront of the Philippines. He was later sent home because of illness. His hospital was destroyed by the atomic bomb on August 9, 1945.

He was planning to reopen a new hospital, but fell ill and died in December 1946 at the age of fifty-five.

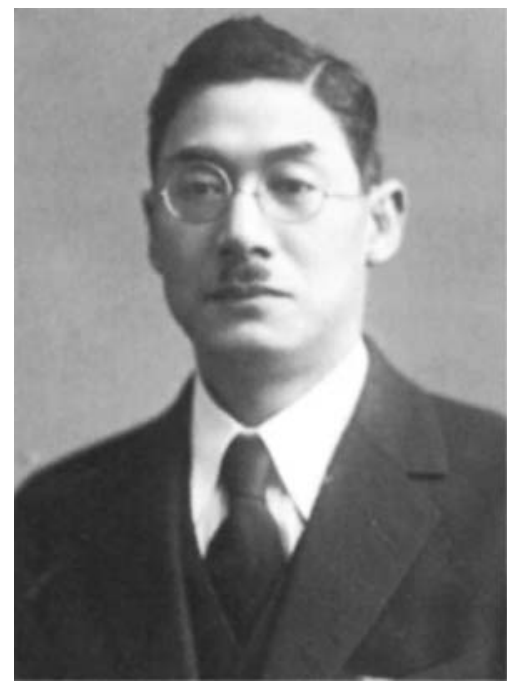

Fig. 12 Einosuke Harada (1892-1946)
The use of the terms Vogt-Koyanagi disease (syndrome) (1939) and Vogt-Koyanagi-Harada disease (syndrome) (since 1955)

In 1939, Jean Babel of the Department of Ophthalmology of Geneva University Hospital, which had been directed since 1933 by Adolphe Franceschetti, reported a case corresponding to the entity described by Koyanagi in his 1929 review article and by Vogt in 1906 [25]. In this article, Babel carried out an extensive literature search on the disease and proposed naming it Vogt-Koyanagi syndrome. He also indicated that the Vogt-Koyanagi syndrome and Harada's disease were very close, almost identical in fact, with the exception that the systemic symptoms were less pronounced in Vogt-Koyanagi syndrome. By 1950, the two terms Vogt-Koyangi disease (syndrome) and Harada's disease (syndrome) were used independently and in parallel. The term Vogt-Koyanagi-Harada disease began to be used in 1955 in about $20 \%$ of the published articles. By 1970 , the majority of articles published used the eponym Vogt-Koyanagi-Harada disease (syndrome) and by 2003 the quasi-totality of authors use the association of the three names for their publications [26].

However, in Japan, in common everyday language, such as in announcements of symposia and workshops, the name 'Harada byô' (Harada disease) is used more often than the full name Vogt-Koyanagi-Harada disease.

\section{Further developments}

Great progress has been made in recent years in terms of increasing our knowledge of the pathogeny of the disease, with more precise investigational techniques enabling optimal follow-up and better guidance in treatment as well as facilitating a more precise definition of the disease as far as nomenclature is concerned. Most of this work originates in Japan. A more detailed description of recent developments will be the subject of a future article, and it is only touched upon here to complete this historical approach.

In the late 1980s, the antigens to which the immune system reacts in VKH disease were identified, mostly from Japanese studies, as melanocyte- 
associated, based on the observation that $\mathrm{T}$ cells from VKH patients were able to be cytotoxic against human melanocytes and melanoma cells [27-28]. A few years later, several groups identified some of the potential antigens. In one report, the MART-1 peptide was isolated as one of the candidates as cytotoxic T lymphocytes recognizing MART-1 peptide were able to lyse melanocytes [29]. Two other antigens subsequently identified were tyrosinase and tyrosinaserelated peptide (TRP) [30]. Similar results were obtained by another group outside Japan which was studying several antigens from the tyrosinase family proteins [31]. Eye-infiltrating cells in VKH patients were later found to react to the same antigens [32]. Since the mid-1990s, researchers have been able to link VKH disease with the presence of the human leukocyte antigen (HLA) DRB1*0405 [33-34], a factor of increased severity in clinical disease and increased T-cell reactivity in vitro [30-31].

More recently, significant progress has also been achieved in monitoring the clinical manifestations of the disease. As the primary target of the autoimmune reaction is within the choroidal stroma, an investigational method able to show the choroidal structures was needed to monitor disease evolution when the disease was subclinical and confined to the choroid after treatment had resolved the clinically apparent inflammation. Indocyanine green angiography (ICGA) was shown to be a very sensitive tool for analyzing choroidal structures in inflammatory diseases [35]. This tool is of particular use as applied to $\mathrm{VKH}$ disease, which is an inflammatory disorder primarily directed against choroidal structures, for which detailed ICG angiography semiology has been described [36]. It has even been shown that subclinical recurrence of choroidal disease is detectable at the time of tapering of inflammation suppressive therapy, a disease recurrence that responded to subsequent increase of therapy [37]. Optimalized treatment can be expected with the help of ICG angiography in the future.

Since 1999, a process aimed at a better defining the disease was developed by Masahiko Usui and Narsing Rao, resulting in workshops in Los Angeles in 1999, Tokyo in 2001, Rome in 2003 and Monte Carlo in 2005. New diagnostic criteria were issued and these are presently being applied in the diagnosis of VKH disease [38].

\section{Conclusion}

Vogt-Koyanagi-Harada disease has gone a long way since its first description by Vogt in 1906, a century ago, when it was called to the attention of the ophthalmological community. The very characteristic behavior of the disease, in contrast to more protean disorders, has probably helped to define the disease without too much delay, thanks to the work of Yoshizo Koyanagi and Einosuke Harada. The characteristic involvement of pigment-containing structures has allowed medical researchers to focus their attention on this aspect of the disease and to identify both risk factors and disease mechanisms. Diagnosis is currently not a major problem, but treatment issues remain, and improved therapy, aided by new sensitive monitoring techniques, including ICG angiography and possibly optical coherence tomography, may be expected in the near future. Further progress in the knowledge of the immunopathology of disease may also result in a more targeted management.

Acknowledgements Both authors would like to express their gratitude to the late Professor Saichi Mishima, who was one of their teachers. His monumental work, carried out with a team of Japanese doctors, on the history of ophthalmology in Japan was used extensively for the ophthalmic historical part of this work. Dr. Herbort would like to thank Dr. Luca Cimino in Italy who encouraged him to undertake this work. Dr. Cimino carried out a literature search, forwarded the original articles and convinced him that he $(\mathrm{CPH})$ was the person predestined to write about the European aspect of VKH as Vogt was Swiss and as the main articles were written either in German, even for the Japanese authors, or in French (for the article that first linked the two names of Vogt and Koyanagi). Thanks are extended from Dr. Herbort to the whole staff of the Department of Ophthalmology and Visual Science of Tokyo Medical and Dental University who warmly welcomed him in their midst and allowed him to plunge into the reality of VKH disease. Thanks also are directed from Dr. Herbort to his wife Naoko who assisted him in this work, critically reviewing its historical part and being very helpful in the translation of some Japanese texts.

\section{References}

1. Vogt A (1906) Frühzeitiges ergrauen der Zilien und Bemerkungen über den sogenannten plötzlichen Eintritt dieser Veränderung. K Monatsbl Augenhk 44:228-242

2. Yamaki K, Gocho K, Hayakawa K, Kondo I, Sakuragi S (2000) Tyrosinase family proteins are antigens speecific to Vogt-Koyanagi-Harada disease. J Immunol 165:73237329 
3. Kobayashi H, Kokubo T, Takahashi M, Sato K, Miyokawa N, Kimura S, Kinouchi R, Katagiri M (1998) Tyrosinase epitope recognized by an HLA-DR-restricted T-cell line from a Vogt-Koyanagi-Harada disease patient. Immunogenetics 47:398-403

4. Mohammad-al-Ghâfiqî. Guide d'Oculistique(translation: E. Meyerhofer, Masnou, Barcelona)

5. Jacobi J (1874) Vorzeitige und akute Entfärbung der Wimpern, beschränkt auf die Lieder eines sympatisch erkrnkten Auges. Klin Monatsbl Augenhk 12:153

6. Tay W (1892) Disease of the eyelids. A case of symmetrical whitening of the eyelashes and eyebrows with sympathetic ophthalmia. Trans Ophthalmol Soc UK 2:29

7. Nettelship RL (1883) Lancet 22:1091

8. Rathinam SR, Namperumalsamy P, Nozik RA, Cunningham ET Jr (1999) Vogt-Koyanagi-Harada syndrome after cutaneous injury. Ophthalmology 106:635-638

9. Komoto J (1912) Ein Beitrag zur Taubheit bei sympatischer Ophthalmie. Klin Monatsbl Augenhk 50:129-135

10. Peters A (1912) Sympatische Ophthalmie und Gehörstörungen. Klin Monatsbl Augenhk 50:433-439

11. Henshall K (2004) A history of Japan from stone age to superpower, 2nd edn. Palgrave Macmillan, New York

12. Shiba R (2004) The last shôgun, the life of Tokugawa Yoshinobu. Kodansha International, Tokyo

13. Mishima S (2004) In: Schmidt G (ed) The history of ophthalmology in Japan, pp 237-239

14. Rintelen F (1979) Zum 100 Geburtstag von Alfred Vogt; Versuch einer Würdigung seines wissenschaftlichen Werkes. Klin Monatsbl Augenhk 178:439-443

15. Schläpfer H, Wagner H (1979) Zum 100 Geburtstag von Professor Dr. Alfred Vogt. Klin Monatsbl Augenhk 178:444-446

16. Rintelen F (1983) 75 Jahresversammlung der Schweizerischen ophthalmologischen Gesellschaft; zu ihrer Gründung und ihren Gründern. Klin Mbl Augenheilk 182:348351

17. Koyanangi Y (1914) Nippon Ganka Gakkai Zasshi $18: 1188$

18. Komoto J (1911) Ueber Vitiligo und Auge. Klin Monatsbl Augenhk 49:139-142

19. Koyanagi Y (1929) Dysakusis, Alopecia und Poliosis bei schwerer Uveitis nicht traumatischen Ursprungs. Klin Monatsbl Augenhk 194-211

20. Hata, Harada E (1918) Jikken Ganka Zasshi 2:199

21. Mishima S (2004) In: Schmidt G (ed) The history of ophthalmology in Japan, Chapter 12, pp 303-338

22. Harada E (1923) Ganka Rinsho Iho 18:69

23. Harada E (1926) Beitrag zur klinischen Kenntniss von nichteitriger Choroiditis (Choroiditis diffusa acuta). Nippon Ganka Gakkai Zasshi 30:356-378

24. Salus R (1932) Harada'sche Krankheit. Klin Mbl Augenheilk 89:84-87

25. Babel J (1939) Syndrome de Vogt-Koyanagi (uvéite bilatérale, poliosis, alopécie, vitiligo et dysacousie). Schweiz Med Wochenschr 44:1136-1140
26. Ooba N (2006) Vogt-Koyanagi-Harada syndrome. Historical changes in the eponym.Nippon Ganka Gakkai Zasshi 110:144-149

27. Maezawa N, Yano A (1984) Two distinct cytotoxic T lyphocyte subpopulations in patients with Vogt-KoyanagiHarada disease that recognize human melanoma cells Microbiol Immunol 28:219-231

28. Norose K, Yano a, Aosai F, Segawa K (1990) Immunologic analysis of cerebrospinal fluid lymphocytes in VogtKoyanagi-Harada disease. Invest Ophthalmol Vis Sci 31:1210-1216

29. Sugita S, Sagawa K, Mochizuki M, Shichijo S, Itoh K (1996) Melanocyte lysis by cytotoxic T lymphocytes recognizing the MART-1 melanoma antigen in HLA-A2 patients with Vogt-Koyanagi-Harada disease. Int Immunol 8:799-803

30. Gocho K, Kondo I, Yamaki K (2001) Identification of autoreactive $\mathrm{T}$ cells in Vogt-Koyanagi-Harada disease. Invest Ophthalmol Vis Sci 42:2004-2009

31. Damico FM, Cunha-Neto E, Goldberg AC, et al. (2005) Tcell recognition and cytokine profile induced by melanocyte epitopes in patients with HLA-DRB1*0405-positive and -negative Vogt-Koyanagi-Harada uveitis. Invest Ophthalmol Vis Sci 46:2465-2471

32. Sugita S, Takase H, Taguchi C, Imai Y, Kamoi K, Kawaguchi T, Sugamoto Y, Futagami Y, Itoh K, Mochizuki M (2006) Ocular infiltrating CD4+ cells from patients with Vogt-Koyanagi-Harada disease recognize human melanocyte antigens. Invest Ophthalmol Vis Sci 2547-2554

33. Islam SM, Numaga J, Fujino Y, Hirata R, Matsuki K, Maeda H, Masuda K (1994) HLA class II genes in VogtKoyanagi-Harada disease. Invest Ophthalmol Vis Sci 35:3890-3896

34. Shindo Y, Inoko H, Yamamoto T, Ohno S (1994) HLADRB1 typing of Vogt-Koyanagi-Harada's disease by PCR-RFLP and the strong association of DRB $1 * 0405$ and DRB1*0410. Br J Opthalmol 78:223-226

35. Herbort CP, LeHoang P, Guex-Crosier Y (1998) Schematic interpretation of indocyanine green angiography in posterior uveitis using a standard protocol. Ophthalmology 105:432-440

36. Bouchenaki N, Herbort CP (2001) The contribution of indocyanine green angiography to the appraisal and management of Vogt-Koyanagi-Harada. Ophthalmology 108:54-64

37. Herbort CP, Mantovani A, Bouchenaki N (2007) Indocyanine green angiography in Vogt-Koyanagi-Harada disease: angiographic signs and utility in patient follow-up. Int Ophthalmol (in press)

38. Read RW, Holland GN, Rao NA, Tabbara KF, Ohno S, Arellanes-Garcia L, Pivetti-Pezzi P, Tessler HH, Usui M (2001) Revised diagnostic criteria for Vogt-KoyanagiHarada disease: report of an international committee on nomenclature. Am J Ophthalmol 131:647-652 